\title{
Pengaruh Substitusi Tepung Labu Kuning (Cucurbita moschata L) terhadap Nilai Gizi Brownies Kukus Labu Kuning
}

\section{Effect of Pumpkin Flour Substitution (Cucurbita Moschata L) on the Nutritional Value of Steamed Pumpkin Brownies}

\author{
Yani Subaktilah $^{\# 1}$, Agung Wahyono*2, Silvia Oktavia Nur Yudiastuti ${ }^{3}$, Qurrota A'yun Mahros ${ }^{4}$ \\ ${ }^{\#}$ Program Studi Teknologi Industri Pangan, Politeknik Negeri Jember, \\ Jl. Mastrip PO. Box 164 Jember, Indonesia \\ ${ }^{1}$ Email: silvia.oktavia@polije.ac.id \\ "Program Studi Teknologi Rekayasa Pangan, Politeknik Negeri Jember, \\ Jl. Mastrip PO. Box 164 Jember, Indonesia
}

\begin{abstract}
Pumpkin is one of an agricultural commodity which is rich in nutrients. Pumpkin also has high vitamin and mineral contents including betacarotene, vitamin $\mathrm{C}$ and vitamin B1. Pumpkin flour is suitable to be added into food products in order to increase the nutrient contents. The study aimed to know the effect of pumpkin flour substitution on the chemical characteristic of steamed brownies. The pumpkin flour substitution were $0 \%, 20 \%, 40 \%, 60 \%, 80 \%$, and $100 \%$ based on wheat flour weight. The result showed that the pumpkin flour substitution significantly increased the moisture contents, ash contents, and carbohydrate contents of steamed brownies. The highest fat content, protein content, and carbohydrate content showed in those of $20 \%$ pumpkin flour substitusion. It contained $29,43 \%$ of fat content, $8,65 \%$ of protein content, and $8,65 \%$ of carbohydrate content, respectively.
\end{abstract}

Keyword : Pumpkin Flour, Steamed Pumpkin Brownies, Cemically Charactersitic

\section{PENDAHULUAN}

Buah labu kuning memiliki daya simpan yang cukup lama. Buah labu kuning dapat disimpan selama 4 bulan sampai sekian tahun selama tidak terdapat luka atau kerusakan pada bagian permukaan kulitnya. Labu kuning juga kaya akan zat gizi. Kandungan vitamin dan mineral labu kuning cukup beragam meliputi beta karoten, vitamin B1, Vitamin C, kalsium, fosfor, besi, kalium dan natrium [4]. Labu kuning juga kaya akan antioksidan yang memiliki beragam manfaat kesehatan. Manfaat labu kuning diantaranya adalah mencegah serangan jantung, stroke, demam, migrain, diare dan penyakit ginjal

Pemanfaatan labu kuning masih belum maksimal. Masyarakat umumnya masih memanfaatkan labu kuning sebagai bahan kolak atau bahan dasar kue tradisional. Industri pangan juga memanfaatkan labu kuning menjadi beberapa macam produk olahan seperti dodol, jelly, maupun manisan.

Untuk meningkatkan daya gunanya, labu kuning dapat diolah menjadi tepung. Labu kuning dalam bentuk tepung berpotensi sebagai bahan tambahan atau pengganti pada produk olahan pangan. berbagai macam laporan penelitian telah mengkaji mengenai fortifikasi tepung labu kuning pada pembuatan puding, es krim, cake basah [5], mie [4], roti [7] dan pancake. Salah satu produk bakery yang memungkinkan untuk dilakukan penambahan atau penggantian sebagian tepungnya adalah brownies. Brownies umumnya terbuat dari tepung terigu yang dicampur dengan bahan lainnya seperti telur, margarin, gula, dan coklat. Brownies memiliki karakteristik yang moist dan tidak memerlukan banyak pengembangan sehingga berpotensi untuk 
dilakukannya penambahan tepung labu kuning ke dalam formulasinya.

Penelitian ini dilakukan untuk mengetahui pengaruh penambahan tepung labu kuning terhadap kandungan gizi brownies kukus. Penambahan tepung labu kuning pada brownies kukus diharapkan dapat meningkatkan kandungan gizinya sehingga dapat menjadi alternatif pemanfaatan bahan pangan lokal dan mengurangi ketergantungan masyarakat akan penggunaan tepung terigu.

\section{MATERI DAN METODE}

\section{A. Bahan dan Alat}

Bahan yang digunakan dalam penelitian ini adalah tepung labu kuning yang berasal dari Kabupaten Jember, gula, tepung terigu protein sedang, telur, margarin, baking powder, $\mathrm{NaOH} 50 \%$, $\mathrm{K}_{2} \mathrm{SO}_{4} 4 \%$, indikator $\mathrm{PP}, \mathrm{H}_{2} \mathrm{SO}_{4}$ pekat, selenium, $\mathrm{HgO}_{2}$, heksan dan akuades.

Alat yang digunakan pada penelitian ini adalah baskom, pengocok telur, food dehydrator, grinder,mixer, inkubator, desikator, tanur, cawan porselen, cawan alumunium, soklet, labu kjeldhal.

\section{B. Tahapan Penelitian}

- Pembuatan Tepung Labu Kuning

Labu kuning dikupas kemudian dilakukan proses pengecilan ukuran. Labu kuning direndam dalam larutan natrium metabisulfit selama 23 menit. Setelah itu ditiriskan dan dikeringkan dengan menggunakan mesin food dehydrator dengan suhu $85^{\circ} \mathrm{C}$ selama 11 jam [7]. Labu kuning kering selanjutnya ditepungkan dan tepung labu kuning yang dihasilkan kemudian di ayak hingga 100 mesh.

\section{- Pembuatan Brownies Kukus}

Proses pembuatan brownies kukus dilakukan dengan mencampur bahan kering berupa tepung terigu,tepung labu kuning dan baking powder. Selanjutnya dilakukan pengocokan telur dan gula. Kemudian ditambahkan dengan bahan kering dan margarin yang telah dicairkan terlebih dahulu. Selanjutnya dilakukan pengadukan bahan. Adonan kemudian dituang pada loyang dan dilakukan proses pengukusan.

\section{- Rancangan Penelitian}

Rancangan penelitian yang digunakan adalah Rancangan Acak Lengkap satu faktor dengan substitusi tepung labu kuning sebesar $0 \%, 20 \%, 40 \%$, $60 \%, 80 \%$, dan $100 \%$. Parameter yang akan di analisa meliputi analisa proksimat yang mencakup analisa kadar air dengan oven suhu $105^{\circ} \mathrm{C}$ selama 3 jam [1] , kadar protein dengan metode mikro kjedahl, kadar lemak dengan metode soxhlet,kadar abu, dan kadar karbohidrat by different. Data yang diperoleh akan dianalisa menggunakan SPSS dengan ANOVA dan apabila terdapat perbedaan akan dilanjutkan dengan Duncan New Multiple Range Test (DNMRT) dengan taraf uji $\alpha \leq 5 \%$.

\section{HASIL DAN PEMBAHASAN}

Analisa yang dilakukan meliputi analisa proksimat untuk mengetahui pengaruh substitusi tepung labu kuning terhadap karakteristik kimia dari brownies kukus labu kuning. Parameter yang dianalisa meliputi kadar air, kadar abu, kadar lemak, kadar protein, dan kadar karbohidrat. Hasil analisa proksimat pada brownies kukus labu kuning dapat dilihat pada Tabel 1 . 
Yani Subaktilah, Agung Wahyono, Silvia Oktavia Nur Yudiastuti, Qurrota A'yun Mahros. Pengaruh Substitusi Tepung Labu Kuning (Cucurbita moschata L) terhadap Nilai Gizi Brownies Kukus Labu Kuning

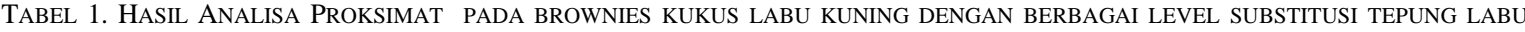
KUNING

\begin{tabular}{|c|c|c|c|c|c|c|c|}
\hline \multirow[t]{2}{*}{ No } & \multirow[t]{2}{*}{ Parameter } & \multicolumn{6}{|c|}{ Tepung Labu Kuning : Tepung Terigu (\%) } \\
\hline & & $0: 100$ & $20: 80$ & $40: 60$ & $60: 40$ & $80: 20$ & $100: 0$ \\
\hline 1 & Kadar air & $22.91 \pm 6.41^{a}$ & $30.01 \pm 3.8^{a}$ & $30.59 \pm 3.7^{\mathrm{a}}$ & $32.65 \pm 1.2^{\mathrm{a}}$ & $31.14 \pm 4.2^{\mathrm{a}}$ & $31.79 \pm 3.24^{\mathrm{a}}$ \\
\hline 2 & Kadar abu & $2.01 \pm 0.49^{a}$ & $2.08 \pm 0.2^{\mathrm{a}}$ & $2.37 \pm 0.13^{\mathrm{a}}$ & $2.52 \pm 0.1^{\mathrm{ab}}$ & $2.56 \pm 0.25^{\mathrm{ab}}$ & $3.03 \pm 0.13^{b}$ \\
\hline 3 & Kadar lemak & $26.64 \pm 0.42^{a b}$ & $29.43 \pm 1.26^{b}$ & $\underset{\mathrm{ab}}{28.85} \pm 1.97$ & $27.81 \pm 1.61^{\mathrm{ab}}$ & $28.32 \pm 2.89^{a b}$ & $24.97 \pm 0.58^{\mathrm{a}}$ \\
\hline 4 & Kadar protein & $7.91 \pm 2.73^{\mathrm{a}}$ & $8.65 \pm 3.64^{\mathrm{a}}$ & $7.33 \pm 2.76^{\mathrm{a}}$ & $8.27 \pm 3.88^{a}$ & $8.3 \pm 1.48^{a}$ & $7.3 \pm 3.25^{\mathrm{a}}$ \\
\hline 5 & $\begin{array}{l}\text { Kadar } \\
\text { karbohidrat }\end{array}$ & $7.91 \pm 2.73^{b}$ & $8.65 \pm 3.64^{a}$ & $7.33 \pm 2.76^{\mathrm{ab}}$ & $8.27 \pm 3.88^{\mathrm{a}}$ & $8.3 \pm 1.48^{\mathrm{a}}$ & $7.3 \pm 3.25^{\mathrm{ab}}$ \\
\hline
\end{tabular}

\section{A. Kadar air}

Hasil analisa proksimat menunjukkan bahwa substitusi tepung labu kuning pada brownies kukus dapat meningkatkan kadar air pada brownies kukus labu kuning. Nilai rata - rata kadar air tertinggi terdapat pada perlakuan penambahan tepung labu kuning sebesar $60 \%$ dan tepung terigu sebesar $40 \%$ sebesar 32,65\%. Peningkatan kadar air pada brownies kukus tidak hanya dipengaruhi oleh tepung labu kuning akan tetapi juga dipengaruhi oleh faktor lain.

Berdasarkan analisa proksimat yang telah dilakukan diketahui bahwa kadar air terendah terdapat pada substitusi tepung labu kuning $20 \%$ dan tepung terigu $80 \%$ dengan rata - rata kadar air sebesar $30,01 \%$ sedangkan nilai tertinggi terdapat pada substitusi tepung labu kuning sebesar $60 \%$ dan tepung terigu $40 \%$ dengan nilai rata - rata kadar air sebesar $32,65 \%$. Hal ini menunjukkan bahwa kadar air brownies kukus labu kuning masih belum memenuhi syarat mutu kadar air brownies berdasar SNI yaitu maksimal kadar air sebesar $16.78 \%$.

\section{B. Kadar $\mathrm{Abu}$}

Semakin tinggi substitusi tepung labu kuning semakin tinggi kadar abu dari brownies kukus labu kuning. Peningkatan kadar abu seiring dengan penambahan jumlah tepung labu kuning terjadi karena tepung labu kuning kaya akan mineral dan vitamin. menurut [3] kandungan mineral dalam labu kuning adalah kalsium $(45,00 \mathrm{mg} / 100 \mathrm{~g})$, fosfor $(64,00 \mathrm{mg} / 100 \mathrm{~g})$ dan besi $(1,40 \mathrm{mg} / 100 \mathrm{~g})$. Nilai kadar abu tepung labu kuning berdasar analisa proksimat adalah sebesar 7,92\%. Nilai kadar abu brownies kukus labu kuning tertinggi berdasar analisa proksimat terdapat pada substitusi tepung labu kuning $100 \%$ yaitu sebesar $3.03 \%$. sementara kadar abu brownies kukus labu kuning terendah berada pada substitusi tepung labu kuning sebesar $20 \%$ yaitu nilai kadar abu rata - rata sebesar $2.08 \%$.

\section{Kadar lemak}

Substitusi tepung labu kuning pada brownies kukus menyebabkan penurunan jumlah kadar lemak brownies kukus. Hal ini dapat terjadi karena kandungan lemak tepung labu kuning lebih rendah dibandingkan dengan kandungan lemak pada tepung terigu. Berdasar analisa proksimat kadar lemak tepung labu kuning sebesar $0,2 \%$ sedangkan kadar lemak tepung terigu menurut [2] adalah sebesar $0,25 \%-0,60 \%$. Pada tabel dapat dilihat bahwa kadar lemak tertinggi pada brownis kukus labu kuning terdapat pada substitusi tepung labu kuning sebesar $20 \%$ yaitu $29,43 \%$

\section{Kadar Protein}

Hasil analisa proksimat menunjukkan bahwa terjadi penurunan kadar protein pada brownies kukus labu kuning seiring dengan semakin bertambahnya jumlah substitusi tepung labu kuning yang ditambahkan. Hal ini dapat terjadi karena kadar protein pada tepung terigu lebih besar dibandingkan dengan kadar protein pada tepung terigu. Hal ini sesuai dengan hasil penelitian [8] yang menyatakan bahwa semakin sedikit konsentrasi penambahan tepung labu kuning maka akan semakin meningkatkan kadar protein pada donat. Hasil analisa menunjukkan bahwa kadar protein tertinggi pada brownies terdapat pada substitusi tepung labu kuning sebesar $20 \%$ yaitu sebesar $8,65 \%$ dan terendah kadar protein brownies pada substitusi tepung labu kuning $100 \%$ yaitu sebesar 7,3\% kadar protein.

\section{E. Kadar karbohidrat}

Substitusi tepung labu kuning pada brownies dapat meningkatkan kadar karbohidrat brownies kukus labu kuning. Hal ini disebabkan karena tepung labu kuning memiliki kandungan karbohidrat cukup 
tinggi. berdasar analisa proksimat diketahui bahwa kadar karbohidrat tepung labu kuning adalah sebesar $85,32 \%$. Pada tabel hasil analisa proksimat pada brownies kukus diketahui bahwa kandungan karbohidrat tertinggi yaitu pada brownies kukus labu kuning dengan substitusi tepung labu kuning 20\% yaitu sebesar $8,65 \%$ kadar karbohidrat.

\section{KeSIMPULAN}

Substitusi tepung labu kuning pada brownies kukus dapat meningkatkan kandungan gizi pada brownies kukus. Semakin tinggi substitusi tepung labu kuning maka semakin tinggi kadar air, kadar abu,dan kadar karbohidrat pada brownies kukus labu kuning. Hasil analisa proksimat menunjukkan bahwa kadar lemak, kadar protein, dan kadar karbohidrat tertinggi pada brownies kukus terdapat pada brownies kukus dengan substitusi tepung labu kuning sebanyak $20 \%$ yaitu masing-masing sebesar $29,43 \%$ kadar lemak, $8,65 \%$ kadar protein, dan $8,65 \%$ kadar karbohidrat.

\section{UCAPAN TERIMA KASIH}

Ucapan terima kasih kami sampaikan pada P3M Politeknik Negeri Jember yang telah mendanai penelitian ini melalui skema sumber dana PNBP Tahun 2020.

\section{DAFTAR PUSTAKA}

[1] AOAC 1995 16th ed. AOAC International, Gaithersbug, Maryland

[2] Astawan, M. 2008. Membuat Mi dan Bihun. Penebar Swadaya, Jakarta.

[3] Hendrasty, H. N., 2003. Tepung Labu Kuning Pembuatan dan Pemanfaatannya. Kanisius, Yogyakarta.

[4] Oloyede, F. M., Agbaje, G. O., Obuotor, E. M., \& Obisesan, I. O. antioxidant profiles of pumpkin Nuraliza, Adam, A., Fadilah, R. 2016. Pengaruh penambahan labu kuning (Cucurbita moschata) dan ubi jalar ungu (Ipomoea batatas L) terhadap kecepatan leleh es krim yang dihasilkan. Jurnal Pendidikan Teknologi Pertanian. Vol 2, S7-S13.

[5] Nurjanah, C.E., Lubis, Y.M., Yusriana. 2017. Pembuatan Mie kering dari Labu Kuning (Cucurbita moschata) dengan variasi hidrokoloid. Jurnal Ilmiah Mahasiswa Pertanian Unsyiah. Volume 2, Nomor 3 , Agustus 2017.

[6] Pramudito dan Salim, C. 2020. Subsitusi Ubi Dengan Labu Kuning Pada Pembuatan Kue Talam. Sekolah Tinggi Pariwisata Trisakti.

[7] Wahyono, A., Kurniawati, E., Kasutjianingati., Park, Kang-Hyun., Kang W W. 2018. Optimasi proses Pembuatan Tepung Labu Kuning Menggunakan Response Methodology Untuk Meningkatkan Aktivitas Antioksidannya. Jurnal Teknologi dan Industri Pangan. Vol 29(1) 29-38. Doi : 10.6066/jtip.2018.29.1.29.
[8] Tamba.M., Ginting.S., Limbong.L.N. 2014.Pengaruh substitusi tepung labu kuning pada tepung terigu dan konsentrasi ragi pada pembuatan donat. J.RekayasaPangan dan Pert.,Vol. 2 No. 2. 